\title{
Mengurangi Stigma Sosial terhadap Penyintas COVID-19 melalui Metode Kontak Bayangan
}

\section{Reducing Social Stigma against COVID-19 Survivors through an Imagined Contact Method}

\author{
Ina Ratnawulan(1)* \& Dicky C. Pelupessy(2) \\ Psikologi Terapan Intervensi Sosial, Fakultas Psikologi, Universitas Indonesia Indonesia \\ Disubmit: 22 Januari 2021; Diproses: 29 Januari 2021; Diaccept: 21 Maret 2021; Dipublish: 05 April 2021 \\ *Corresponding author: E-mail: : ina.ratnawulan@ui.ac.id; ina.ratnawulan@gmail.com
}

\begin{abstract}
Abstrak
Dalam situasi pandemi yang penuh dengan kecemasan akan penularan COVID-19 dan belum ditemukannya obat yang dapat menyembuhkan penyakit ini, penyintas COVID-19 sangat rentan untuk mengalami stigma sosial. Dengan mengacu pada gagasan Contact Hypothesis dari Allport (1954) yang menyatakan bahwa kontak antarkelompok dapat mengurangi prasangka, peneliti memandang bahwa dalam situasi pandemi COVID-19 sulit untuk menciptakan suatu kondisi yang ideal untuk melaksanakan proses kontak antarkelompok. Oleh karenanya, peneliti berinisiatif untuk melakukan penelitian terkait stigma sosial terhadap penyintas COVID-19 dengan menggunakan metode kontak antarkelompok secara tidak langsung melalui metode kontak bayangan sebagaimana dikembangkan oleh Pettigrew (1998). Penelitian ini bertujuan untuk menguji efektivitas metode kontak bayangan dalam mengurangi stigma sosial terhadap penyintas COVID-19. Hasil penelitian menunjukkan bahwa metode kontak bayangan dapat mengurangi stigma sosial secara signifikan dan hal ini didukung oleh adanya perilaku positif untuk mendukung kampanye anti stigma oleh $80 \%$ partisipan program intervensi.
\end{abstract}

Kata Kunci: COVID-19; Intervensi; Kontak Bayangan; Penyintas; Stigma

\begin{abstract}
In a pandemic situation that is full of anxiety about the transmission of COVID-19 and with the fact that there was no medicine that has been proven to cure the disease effectively, COVID-19 survivors are very vulnerable to experiencing social stigma. Referring to the idea of Contact Hypothesis from Allport (1954) which states that intergroup contact can reduce prejudice, the researcher views that in a COVID-19 pandemic situation it is difficult to create an ideal condition for carrying out the inter-group contact process. Therefore, researchers took the initiative to conduct research related to social stigma towards COVID-19 survivors by using the indirect inter-group contact method through the imagined contact method as developed by Pettigrew (1998). This study aims to test the effectiveness of imagined contact methods in reducing social stigma against COVID-19 survivors. The results showed that the imagined contact method could significantly reduce social stigma and this was supported by positive behavior to support the anti-stigma campaign by 80\% of the participants of the intervention program.
\end{abstract}

Keywords: COVID-19; Imagined Contact; Intervention; Stigma; Survivor

DOI: https://doi.org/10.51849/j-p3k.v2i1.89

Rekomendasi mensitasi :

Ratnawulan, I., \& Pelupessy, D, C. 2021, Mengurangi Stigma Sosial terhadap Penyintas COVID-19 melalui Metode Kontak Bayangan. Jurnal Penelitian Pendidikan, Psikologi dan Kesehatan (J-P3K), 2 (1): 52-60. 


\section{PENDAHULUAN}

Pandemi

COVID-19

membawa dampak yang sangat besar pada berbagai aspek kehidupan masyarakat dan negara. Pada awal Desember 2020, kasus COVID19 di seluruh dunia berjumlah 64.934.641 kasus, mengakibatkan kematian terhadap 1.501.313 jiwa, sementara jumlah yang telah sembuh (dikenal dengan 'survivor' atau penyintas COVID-19) berjumlah 45.029.982 jiwa. Di Indonesia sendiri jumlah kasus terkonfirmasi COVID-19 pada awal Desember 2020 adalah 557.887 kasus, 17.355 jiwa meninggal dunia dan penyintas COVID-19 sejumlah 462.553 jiwa (Worldometers, 2020).

Tingginya jumlah kasus yang terkonfirmasi dan kematian akibat COVID19 menimbulkan kecemasan dan ketakutan pada masyarakat (C.-Y. Lin, 2020). Dalam penelitiannya, Ahorsu et al. (2020) menyatakan bahwa ketakutan yang tinggi untuk berinteraksi dengan mereka yang diasosiasikan dengan COVID-19 pada faktanya dapat membuat masyarakat tidak berpikir secara jernih dan rasional dalam berhadapan dengan kasus-kasus COVID-19 (Ahorsu et al., 2020).

Ketakutan akan sesuatu yang tidak diketahui dan tidak biasa (unfamiliar) serta kurangnya pengetahuan dan informasi terhadap suatu penyakit yang belum ditemukan obat untuk penyembuhannya seringkali menimbulkan persepsi negatif, termasuk stigma, serta menjadi justifikasi atas pengasingan terhadap mereka yang memiliki kondisi kesehatan tersebut (C. Lin, 2020; Williams, Gonzalez-Medina, \& Vu Le, 2011).

Pada Agustus 2020, Lapor Covid-19 dan Kelompok Peminatan Intervensi Sosial Fakultas Psikologi Universitas Indonesia melakukan survei terkait pengalaman stigma COVID-19 terhadap partisipan yang sedang terpapar dan penyintas COVID-19. Hasil survei menunjukkan bahwa fenomena stigma terkait COVID-19 nyata adanya dan stigma sosial tidak hanya dikenakan terhadap mereka yang terpapar COVID-19, namun dikenakan juga kepada penyintas COVID-19.

Dengan adanya fenomena psikososial serta keterbatasan dalam melakukan penelitian, peneliti memfokuskan pada upaya intervensi untuk menurunkan stigma sosial terhadap penyintas COVID19. Berdasarkan penelusuran literatur, terdapat tiga strategi yang dapat digunakan untuk melawan stigma yaitu melalui protes, pendidikan dan kontak (Betton et al., 2015; Hackler, 2011; Rüsch, Angermeyer, \& Corrigan, 2005). Dari ketiga strategi tersebut, penulis memilih untuk menggunakaan strategi kontak.

Berdasarkan Contact Hypothesis, kontak interpersonal yang dekat dan menyenangkan antara orang-orang dari kelompok yang berbeda mungkin adalah cara terbaik untuk mencapai harmoni sosial (Allport, 1954). Beberapa penelitian menunjukkan bahwa Contact Hypothesis efektif untuk menurunkan stigma terhadap kelompok minoritas dan kelompok yang terstigma (Hackler, 2011) dan terbukti menunjukkan efektivitasnya dalam memperbaiki hubungan antarkelompok (Pettigrew \& Tropp, 2006; Turner, Crisp, \& Lambert, 2007; Vezzali, Capozza, Stathi, \& Giovannini, 2012).

Menurut Crisp, Stathi, Turner dan Husnu (2009) efektivitas suatu kontak untuk menurunkan tingkat prasangka hanya terjadi apabila masing-masing kelompok memiliki kesempatan untuk 
melakukan kontak. Namun dalam situasi pandemi COVID-19, kontak antarkelompok sulit untuk dilakukan karena berpotensi meningkatkan risiko paparan COVID-19. Oleh karenanya, upaya intervensi yang dilakukan adalah melalui metode kontak bayangan.

Kontak bayangan didefinisikan sebagai tindakan membayangkan diri sendiri dalam interaksi sosial yang positif dengan anggota kelompok lain (Crisp, Stathi, Turner, \& Husnu, 2008; Debineva, 2019; Miles \& Crisp, 2014). Menurut Crisp dan Turner (2009) ketika individu berhasil melakukan interaksi yang positif dengan anggota kelompok lain, maka tingkat kecemasan antarkelompok akan cenderung turun, karena mereka menyadari bahwa tidak ada hal yang perlu ditakutkan dari interaksi tersebut (Crisp \& Turner, 2009).

Menurut Allport (1954) dan dari beberapa penelitian lainnya, metode kontak bayangan terbukti mampu menghasilkan hasil evaluasi yang lebih positif yang mirip dengan efek kontak langsung, interaksi tatap muka atau ceramah (Debineva, 2019; Voci \& Hewstone, 2003). Metode kontak bayangan juga terbukti dapat meningkatkan kepercayaan dan meningkatkan niat berperilaku terhadap kelompok lain sehingga dapat digunakan sebagai pre-contact tool atau langkah awal sebelum memasuki kontak (langsung) antarkelompok (Vezzali et al., 2012).

Menurut Crisp et al., (2009), terdapat dua elemen penting yang harus muncul dalam instruksi kontak bayangan yaitu 1) Simulasi mental mengenai interaksi sosial antara anggota 'ingroup' dan anggota 'outgroup' dan 2) Interaksi yang dibayangkan bernuansa positif ('Positif Tone').

Ketiadaan nuansa interaksi yang positif justru dapat meningkatkan kecemasan antarkelompok karena partisipan akan memanfaatkan informasi yang paling mudah diakses tentang outgroup, antara lain adalah stereotip negatif, terutama ketika kelompok lain tersebut sangat distigmatisasi dan dianggap mengancam. (West \& Greenland, 2016).

Berdasarkan hal-hal tersebut di atas, peneliti melakukan sebuah penelitian yang bertujuan untuk menguji efektivitas metode kontak bayangan dalam menurunkan stigma sosial terhadap penyintas COVID-19. Pernyataan hipotesis dalam penelitian ini adalah kontak bayangan dapat mengurangi stigma sosial secara signifikan terhadap penyintas COVID-19.

\section{METODE PENELITIAN}

Partisipan dalam penelitian berjumlah 25 orang, berusia di atas 18 tahun dan tidak pernah terpapar COVID19, yang dipilih dengan metode purposive sampling sehingga mayoritas partisipan adalah mereka yang masuk kategori stigma sosial tinggi dengan mengacu pada hasil pengukuran stigma sosial pada baseline yang sebelumnya telah dilakukan oleh peneliti. Partisipan terdiri dari 17 orang perempuan dan 8 orang laki-laki.

Partisipan diikutsertakan dalam satu kali program intervensi yang berdurasi maksimal enam puluh menit melalui pertemuan virtual. Adapun instruksi yang digunakan merupakan modifikasi dari instruksi kontak bayangan dari penelitian Vezzali, Capozza, Stathi, dan Giovannini 
(2012) pada sebuah artikel jurnal yang berjudul "Increasing outgroup trust, reducing infrahumanization, and enhancing future contact intention via imagined intergroup contact.".

Setiap partisipan diminta untuk membayangkan terjadinya suatu interaksi yang nyaman dan menyenangkan dengan seseorang yang tidak dikenal yang diketahui merupakan seorang penyintas COVID-19 dalam tiga skenario yang berbeda tingkat kesulitannya. Pada skenario pertama partisipan diminta membayangkan berinteraksi dengan tetangga baru penyintas COVID-19, skenario kedua berinteraksi dengan penyintas COVID-19 di ruang tunggu pelayanan publik dan skenario ketiga berinteraksi dengan penyintas COVID-19 dalam suatu pertemuan yang tidak dapat dihindari.

Di antara masing-masing skenario, peneliti memberikan jeda waktu kepada partisipan untuk melepaskan bayangan dari skenario sebelumnya sekitar kurang lebih satu menit dengan memutarkan musik yang santai atau berfoto bersama.

Untuk menguatkan efek dari metode kontak bayangan, masing-masing partisipan juga diminta untuk menuliskan bayangannya secara detail antara lain ciriciri fisik (perempuan atau laki-laki, tinggi dan berat badan, atau karakter lainnya), apa yang dilakukan dan apa yang dikatakan sehingga interaksi berjalan dengan santai, nyaman dan menyenangkan. Menurut Husnu \& Crisp (2010), penggambaran detail seperti ini akan menguatkan efek metode kontak bayangan.

Contoh instruksi yang diberikan adalah sebagai berikut:
"Saya ingin meminta Anda untuk membayangkan situasi ketika seorang yang sebelumnya tidak dikenal menempati rumah di sebelah tempat tinggal Anda dan Anda mendapatkan informasi bahwa ia adalah seorang penyintas COVID-19. Pada suatu waktu, secara tidak sengaja Anda berpapasan dengan tetangga tersebut di depan rumah Anda. Saya minta Anda membayangkan bagaimana ciri-ciri fisik tetangga penyintas COVID-19 tersebut, apa yang akan Anda ucapkan dan lakukan hingga akhirnya Anda dan tetangga tersebut terlibat dalam percakapan yang santai, nyaman dan menyenangkan.

Saya mempersilakan Anda untuk membayangkan, kemudian menuliskan apa yang ada dalam bayangan Anda kepada peneliti.

Apakah instruksi saya sudah jelas? Jika sudah jelas, saya persilakan Anda untuk mulai membayangkan dan menuliskan kepada kami melalui fitur 'chat'. Waktu untuk aktivitas ini adalah tiga menit dimulai dari sekarang."

Setelah aktivitas membayangkan dan menuliskan, partisipan akan diminta untuk menyampaikan apa yang dibayangkan dalam diskusi singkat selama dua sampai lima menit. Semua aktivitas ini dilakukan untuk setiap skenario. Setelah keseluruhan rangkaian program intervensi selesai dilakukan, peneliti menutup pertemuan virtual dengan pemberian debriefing. Setelah itu partisipan akan diminta untuk mengisi kuesioner stigma sosial sebagai bentuk post-test. Kuesioner yang diberikan untuk post-test adalah sama dengan kuesioner saat baseline (pre-test). 


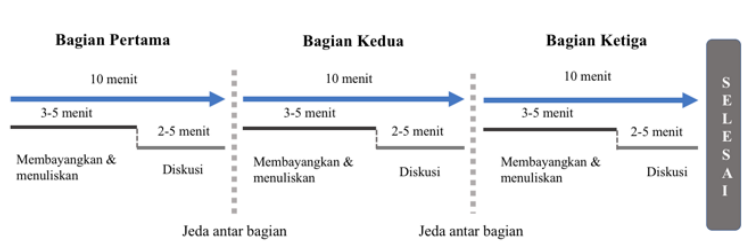

Gambar 1 Alokasi Waktu Program Intervensi

Dengan keterbatasan ketersediaan alat ukur stigma sosial terkait COVID-19, peneliti melakukan adaptasi terhadap alat ukur Stigma Sosial terkait penyakit HIV/AIDS dengan mengacu pada jurnal yang ditulis oleh Visser, Kershaw, Makin, dan Forsyth (2008) yang berjudul Development of Parallel Scales to Measure HIV-Related Stigma Pretoria / Medical Research Unit for Maternal and Infant Health Care (Visser, Kershaw, Makin, \& Forsyth, 2008), khususnya pada alat ukur stigma dari perspektif sikap pribadi individu (personal attitudes held by individuals).

Adaptasi alat ukur ini dilakukan mengingat kesamaan karakteristik COVID19 dengan HIV/AIDS yaitu sebagai penyakit yang disebabkan oleh virus baru yang tidak pernah dihadapi sebelumnya oleh manusia (AJMC, 2019) dan kedua, memenuhi kriteria penyakit yang erat dikaitkan dengan stigma berdasarkan pernyataan WHO (2020) dan penelitian Williams et. al (2011).

Koefisien konsistensi internal alat ukur stigma sosial adalah Cronbach's Alpha $=0,858$ lebih dari nilai standar yaitu 0,7. Dengan demikian instrumen stigma sosial reliabel dan nilai Corected Item-Total Correlation masing-masing pertanyaan lebih dari nilai standar yaitu 0,113 sehingga semua pertanyaan valid.

Alat ukur stigma ini memiliki 12 item yang terdiri dimensi Blame and Judgment
(6 item) dan Interpersonal Distance (6 item) dan menggunakan Skala Likert 4 poin, dengan pilihan jawaban rentang 1 ("Sangat Tidak Setuju") hingga 4 ("Sangat Setuju"). Dari skoring tersebut, skor yang didapatkan oleh partisipan untuk stigma sosial adalah antara 12-39. Peneliti membagi skor ini ke dalam dua kategori berdasarkan nilai tengah dimana 24 sampai dengan 39 adalah "stigma tinggi" dan 12 sampai dengan 23 adalah "stigma rendah".

Untuk mengetahui keberhasilan hasil intervensi berupa penurunan sikap negatif terhadap penyintas COVID-19, peneliti membandingkan hasil pre-test partisipan yang diperoleh saat melakukan studi baseline dengan hasil post-test setelah program intervensi dengan melakukan analisa paired sample t-test. Teknik ini digunakan untuk melihat signifikansi perbedaan rata-rata sebelum dan sesudah diberikan intervensi.

Beberapa hari setelah intervensi dilaksanakan, peneliti mengirimkan pesan melalui whatsapp kepada partisipan yang berisi ajakan untuk melakukan kampanye anti stigma dengan menayangkan tulisan pendek, poster atau video terkait anti stigma terhadap penyintas COVID-19 di media sosial masing-masing, serentak pada hari dan waktu yang ditentukan peneliti.

Partisipan yang bersedia menayangkan kampanye anti stigma diminta untuk mengirimkan bukti dari kampanye yang dilakukan kepada peneliti. Peneliti memantau kesediaan partisipan untuk berpartisipasi sebagai indikator perubahan perilaku. 


\section{HASIL DAN PEMBAHASAN}

Berikut ini adalah gambaran umum partisipan penelitian berdasarkan jenis kelamin, ada atau tidak adanya kontak serta kategori stigma sosial.

Tabel 1. Gambaran Umum Partisipan Penelitian

\begin{tabular}{llc}
\hline & & Partisipan \\
\hline \multirow{2}{*}{ Jenis Kelarnin } & $\mathrm{P}$ & 17 \\
& $\mathrm{~L}$ & 8 \\
\cline { 2 - 3 } Kontak & Ya & 14 \\
& Tidak & 11 \\
\cline { 2 - 3 } Stigma & Tinggi & 22 \\
$\mathrm{~N}$ & Rendah & 3 \\
\cline { 2 - 3 } & & 25 \\
\hline
\end{tabular}

Sementara perbandingan hasil rata-rata pre-test dan post-test partisipan dituangkan dalam tabel-tabel berikut ini:

Tabel 2. Uji Perbedaan Hasil Pre-test dan Post-test

\begin{tabular}{lllcrr}
\multicolumn{5}{c}{ Paired Samples Statistics } \\
\hline & & & & \multicolumn{2}{c}{ Std. Error } \\
& & Mean & N & Std.Deviation & \multicolumn{1}{c}{ Mean } \\
\hline Pair 1 & Stigma_skor_pre & 28,28 & 25 & 4,188 &, 838 \\
& Stigma_skor_post & 24,08 & 25 & 5,859 & 1,172 \\
Pair 2 & B__pre & 13,48 & 25 & 2,293 &, 459 \\
& BJ_post & 11,80 & 25 & 2,843 &, 569 \\
Pair 3 & ID_pre & 14,80 & 25 & 2,198 &, 440 \\
& ID_post & 12,28 & 25 & 3,221 &, 644 \\
\hline
\end{tabular}

Tabel 3. Uji Paired Samples Correlations

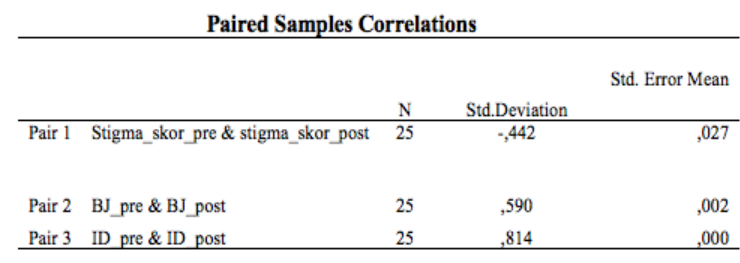

Tabel 4. Uji Paired Samples Test

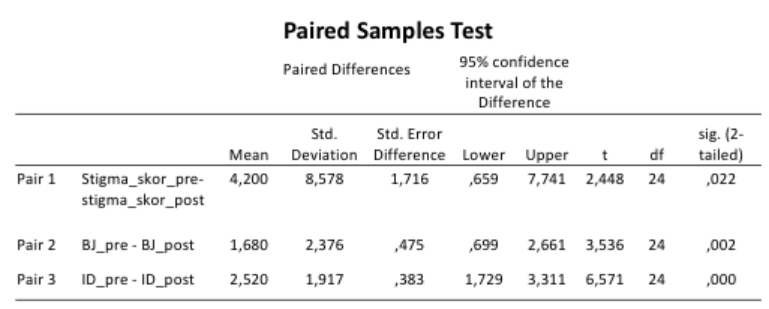

Nilai sig (2 tailed) pada stigma total, BJ, dan ID masing-masing < 0,05 (intervensi memiliki hubungan mengubah rata-rata pre-test dan post-test secara signifikan). Nilai sig (1 tailed) pada stigma total, BJ, dan ID masing-masing < 0,05 (intervensi menurunkan rata-rata pre-test dan post-test secara signifikan).

Tabel di atas menunjukkan bahwa rata-rata partisipan mengalami penurunan stigma sosial terhadap penyintas COVID19 pada saat post-test dibandingkan pada saat pre-test. Hal ini ditunjukkan dengan adanya penurunan Mean pada Blame and Judgement dari 13.480 menjadi 11.800 .

Hasil uji t berpasangan menunjukkan bahwa penurunan ini signifikan pada taraf $5 \%$ karena p-value lebih kecil dari 0.05 $(\mathrm{t}(24)=3.536, \mathrm{p}<0.001)$. Mean pada Interpersonal Distance juga mengalami penurunan setelah diberikan intervensi dari 14.800 menjadi 12.280. Hasil uji t berpasangan menunjukkan bahwa penurunan ini juga signifikan karena pvalue lebih kecil dari $0.05(\mathrm{t}(24)=6.571, \mathrm{p}$ $<0.001$ ).

Sementara untuk indikator perubahan perilaku dari pelaksanaan Kampanye Anti Stigma, partisipan yang tercatat turut serta dalam kampanye sesuai dengan ajakan peneliti adalah sebesar $80 \%$ (delapan puluh persen) ditambah dengan satu orang partisipan yang memilih untuk langsung mendatangi rumah tetangga penyintas COVID-19 untuk memberikan makanan. Sehingga total partisipan yang menunjukkan perilaku positif adalah sebesar 84\% (delapan puluh empat persen).

Hasil analisa statistik menunjukkan bahwa kontak bayangan berpengaruh secara signifikan untuk mengurangi stigma sosial pada partisipan program intervensi terhadap penyintas COVID-19 (Nilai p < $0,05)$. Adapun dari dua dimensi alat ukur 
stigma sosial yang terdiri dari Blame \& Judgement dan Interpersonal Distancing keduanya juga menunjukkan adanya penurunan Mean yang signifikan (Nilai $\mathrm{p}<$ $0,05)$.

Keberhasilan metode kontak bayangan yang dilakukan sangat didukung oleh instruksi untuk membayangkan dan menuliskan interaksi secara detail dan proses diskusi yang dilakukan pada akhir setiap bagian intervensi. Selain membayangkan dan menuliskan yang menguatkan efek kontak bayangan (Husnu \& Crisp, 2010; Vezzali et al., 2012) aktivitas diskusi memiliki potensi untuk menimbulkan reaksi positif (empati, toleransi) daripada negatif (cemas, gelisah) pada partisipan.

Turner et al. (2007) menyatakan bahwa melihat seorang anggota ingroup menunjukkan toleransi terhadap outgroup dapat memberikan pengaruh yang positif pada sikap anggota ingroup tersebut (Turner et al., 2007).

Selain itu, peneliti mengidentifikasi bahwa partisipan dapat merefleksikan empati ketika diskusi dilakukan. Adanya perasaan empati dari partisipan tersebut membuat partisipan yang bersangkutan tidak dengan mudah menghindari percakapan dengan penyintas COVID-19 dan hal ini pada akhirnya akan berdampak pada penurunan kecemasan dalam melakukan kontak antarkelompok.

Hal ini sejalan dengan gagasan Pettigrew dan Trop (2008) bahwa kontak menurunkan prasangka dengan (1) meningkatkan pengetahuan tentang kelompok lain, (2) mengurangi kecemasan terkait kontak antarkelompok, dan (3) meningkatkan empati dan sudut pandang seseorang (Pettigrew \& Tropp, 2008).
Beberapa hal lainnya yang menjadi catatan pada proses intervensi secara virtual adalah sebagai berikut: kesediaan partisipan harus didukung dengan jaringan internet yang cukup baik, ketersediaan perangkat komunikasi dengan fitur audio visual yang memadai (komputer atau smart phone), serta adanya komitmen untuk menghadiri sesi intervensi secara tepat waktu agar dapat mengikuti keseluruhan rangkaian program intervensi.

Rangkaian penelitian ini adalah proses membangun kepercayaan dan dukungan dari partisipan. Peneliti perlu membangun nuansa yang positif agar program intervensi secara virtual berjalan dengan santai, nyaman dan tidak kaku, namun tetap disertai dengan instruksi yang jelas. Hal ini perlu mendapat perhatian agar para partisipan tetap dapat berpartisipasi secara aktif meskipun tidak saling mengenal dan merasa nyaman dalam menjalani program intervensi yang berdurasi maksimal enam puluh menit.

\section{SIMPULAN}

Hasil penelitian menunjukkan bahwa metode kontak bayangan efektif dalam mengurangi stigma terhadap penyintas COVID-19 secara signifikan. Hal ini ditunjukkan dengan hasil analisa statistik berupa penurunan Mean secara signifikan pada dimensi Blame and Judgement dan Interpersonal Distance. Dengan demikian pernyataan hipotesis penelitian diterima bahwa metode kontak bayangan mengurangi stigma sosial terhadap penyintas COVID-19 secara signifikan.

Adapun untuk perubahan perilaku, prosentase partisipan yang bersedia untuk ikut serta dalam kampanye anti stigma dan 
melakukan perilaku positif terhadap penyintas COVID-19 mencapai delapan puluh empat persen. Hal ini menunjukkan adanya perubahan perilaku yang positif dari mayoritas partisipan sebagian besar masuk dalam kategori skala stigma tinggi. Artinya, metode kontak bayangan yang dirancang dalam penelitian ini cukup mampu mendorong perubahan sampai pada respons kognitif, afektif dan perilaku (Pettigrew, 1998).

\section{DAFTAR PUSTAKA}

Ahorsu, D. K., Lin, C. Y., Imani, V., Saffari, M., Griffiths, M. D., \& Pakpour, A. H. (2020). The Fear of COVID-19 Scale: Development and Initial Validation. International Journal of Mental Health and Addiction. https://doi.org/10.1007/s11469-020-00270-8

AJMC. (2019). Challenges and Similarities in HIV, COVID-19 Crises: A Q\&A With Anthony Fauci, MD. https://doi.org/https://doi.org/10.37765/aj mc.2020.43637

Allport, F. H. (1954). The restructuring of events: Outline of a general theory with applications to psychology. Psychological Review, 281-303.

Betton, V., Borschmann, R., Docherty, M., Coleman, S., Brown, M., \& Henderson, C. (2015). The role of social media in reducing stigma and discrimination. British Journal of Psychiatry, 206(6), 443-444. https://doi.org/10.1192/bjp.bp.114.152835

Crisp, R. J., Stathi, S., Turner, R. N., \& Husnu, S. (2008). Imagined intergroup contact: Theory, paradigm, and practice. Social and Personality Psychology Compass, 2, 1-18. https://doi.org/10.1111/j.17519004.2008.00155.x

Crisp, R. J., Stathi, S., Turner, R. N., \& Husnu, S. (2009). Imagined intergroup contact: Theory, paradigm, and practice. Social and Personality Psychology Compass, 3(6), 11291134. https://doi.org/10.1111/j.17519004.2009.00230.X

Crisp, R. J., \& Turner, R. N. (2009). Can imagined interactions produce positive perception? Reducing prejudice through simulated social contact. American Psychologist. https://doi.org/https://doi.org/10.1037/aoo1 4718
Debineva, F. (2019). Mengurangi prasangka negatif terhadap transpuan dengan metode kontak imajiner melalui photovoice kepada orang muda di tangerang, indonesia. https://doi.org/DOI: 10.15294/intuisi.v11i1.20113

Hackler, A. H. (2011). Contact and stigma toward mental illness: Measuring the effectiveness of two video interventions. Dissertation Abstracts International: Section B: The Sciences and Engineering, 72(12-B), 7716. https://doi.org/https://doi.org/10.31274/etd $-180810-1316$

Husnu, S., \& Crisp, R. J. (2010). Elaboration enhances the imagined contact effect. Journal of Experimental Social Psychology, 46(6), 943-950. https://doi.org/10.1016/j.jesp.2010.05.014

Kobau, R., Zack, M. M., Luncheon, C., Barlie, J. P., Chris, M., Bomemann, T., ... Morales, D. S. (2012). Attitude toward mental illness: Result from the behavioral risk factor surveillance system.

Lin, C.-Y. (2020). Social Health and Behavior. Social Health and Behavior, 3(1), 1-2. https://doi.org/10.4103/SHB.SHB

Lin, C. (2020). Social reaction toward the 2019 novel coronavirus (COVID-19). Social Health and Behavior [Serial Online]. https://doi.org/10.4103/SHB.SHB_11_20

Miles, E., \& Crisp, R. J. (2014). A meta-analytic test of the imagined contact hypothesis. Group Processes and Intergroup Relations, 17(1), 326. https://doi.org/10.1177/1368430213510573

Pettigrew, T. F. (1998). Intergroup contact theory. Annual Review of Psychology, 49(1), 65-85. https://doi.org/10.1146/annurev.psych.49.1.6 5

Pettigrew, T. F., \& Tropp, L. R. (2006). A metaanalytic test of intergroup contact theory. Journal of Personality and Social Psychology, 9o(5), 751-783. https://doi.org/10.1037/oo223514.90.5.751

Pettigrew, T. F., \& Tropp, L. R. (2008). How does intergroup contact reduce prejudice? Metaanalytic test of three mediators. European Journal of Social Psychology Eur., 38(March 2008), 922-934. https://doi.org/10.1002/ejsp

Rüsch, N., Angermeyer, M. C., \& Corrigan, P. W. (2005). Mental illness stigma: Concepts, consequences, and initiatives to reduce stigma. European Psychiatry, 2o(8), 529-539. https://doi.org/10.1016/j.eurpsy.2005.04.004

Turner, R. N., Crisp, R. J., \& Lambert, E. (2007). Imagining intergroup contact can improve intergroup attitudes. Group Processes and 
Intergroup Relations, 10(4), 427-441. https://doi.org/10.1177/1368430207081533

Vezzali, L., Capozza, D., Stathi, S., \& Giovannini, D. (2012). Increasing outgroup trust, reducing infrahumanization, and enhancing future contact intentions via imagined intergroup contact. Journal of Experimental Social Psychology, 48(1), 437-440. https://doi.org/10.1016/j.jesp.2011.09.008

Visser, M. J., Kershaw, T., Makin, J. D., \& Forsyth, B. W. C. (2008). Development of Parallel Scales to Measure HIV-Related Stigma Pretoria / Medical Research Unit for Maternal and Infant Health Care.

Voci, A., \& Hewstone, M. (2003). Intergroup contact and prejudice toward immigrants in Italy: The mediational role of anxiety and the moderational role of group salience. https://doi.org/https://doi.org/10.1177/1368 430203006001011

West, K., \& Greenland, K. (2016). Beware of "reducing prejudice": imagined contact may backfire if applied with a prevention focus. Journal of Applied Social Psychology. https://doi.org/https://doi.org/10.1111/jasp.1 2387

WHO. (2013). Stigma and Discrimination. Retrieved July 15, 2020, from https://www.euro.who.int/en/healthtopics/noncommunicable-diseases/mentalhealth/priority-areas/stigma-and-

discrimination

WHO. (2020). Social Stigma associated with COVID-19 A guide to preventing and addressing, (February), 1-5.

Williams, J. L., Gonzalez-Medina, D. J., \& Vu Le, Q. (2011). Infectious diseases and social stigma. Medical and Health Science Journal, 7(3), 214. https://doi.org/10.15208/mhsj.2011.127

Worldometers. (2020). Covid-19 Coronavirus Pandemic. Retrieved December 5, 2020, from

https://www.worldometers.info/coronaviru s/\#countries 